\title{
Effect of six tropical tanniferous plant extracts on larval exsheathment of Haemonchus contortus
}

Efeito de seis extratos de plantas taniníferas tropicais sobre o desembainhamento larvar de Haemochus contortus

\author{
Lorena Mayana Beserra de Oliveira'; Claudia Maria Leal Bevilaqua ${ }^{1 *}$; Iara Tersia Freitas Macedo; \\ Selene Maia de Morais ${ }^{1}$; Maria Vivina Barros Monteiro ${ }^{1}$; Claudio Cabral Campello후 \\ Wesley Lyeverton Correia Ribeiro ${ }^{1}$; Emanuelle Karine Frota Batista ${ }^{2}$
}

${ }^{1}$ Programa de Pós-Graduação em Ciências Veterinárias, Universidade Estadual do Ceará - UECE

${ }^{2}$ Departamento de Veterinária, Universidade Federal do Piauí - UFPI

Received December 7, 2010

Accepted January 24, 2011

\begin{abstract}
Tanniferous plants represent a promising alternative for controlling gastrointestinal nematodes of small ruminants. This experiment evaluated the effects of extracts from the leaf and stem of Anadenanthera colubrina, Leucaena leucocephala and Mimosa tenuiflora on larval exsheathment of Haemonchus contortus in vitro and verified the role of tannins in this process. Third-stage larvae of $H$. contortus were incubated with extracts for 3 hours and were exposed to sodium hypochlorite solution. The extracts were tested at $300 \mu \mathrm{g} \cdot \mathrm{mL}^{-1}$ and accompanied by controls: phosphate buffer solution (PBS) and polyvinyl polypyrrolidone (PVPP). The larval exsheathment was evaluated for 60 minutes, and the results were subjected to the Kruskal-Wallis test $(\mathrm{p}<0.05)$. The six extracts blocked larval exsheathment. After PVPP addition, a tannin inhibitor, the exsheathment percentage was similar to the PBS ( $\mathrm{p}>0.05$ ), except for L. leucocephala and $M$. tenuiflora leaf extracts. However, pre-incubation with PVPP of these two extracts significantly changed larval exsheathment when compared to the non-treated extracts $(\mathrm{p}<0.05)$. These results suggest that $A$. colubrina, L. leucocephala and M. tenuiflora could be useful in gastrointestinal nematode control and that tannins are probably the main compounds involved in the observed effects. However, in vivo and toxicological studies should be conducted.

Keywords: In vitro, tannins, polyvinyl polypyrrolidone, helminth control, phytotherapics.
\end{abstract}

\section{Resumo}

Plantas taniníferas representam uma promissora alternativa de controle dos nematóides gastrintestinais de pequenos ruminantes. Esse experimento avaliou in vitro os efeitos dos extratos das folhas e caules de Anadenanthera colubrina, Leucaena leucocephala e Mimosa tenuiflora sobre o desembainhamento larvar de Haemonchus contortus e verificou o papel dos taninos nesse processo. Larvas de terceiro estádio de $H$. contortus foram incubadas com $300 \mu \mathrm{g} \cdot \mathrm{mL}^{-1} \mathrm{de}$ extrato por 3 horas e expostas a uma solução de hipoclorito de sódio. $\mathrm{O}$ ensaio foi acompanhado por controles: solução salina tamponada com fosfato (PBS) e polivinilpolipirrolidona (PVPP). O desembainhamento larvar foi avaliado durante 60 minutos e os resultados submetidos ao teste Kruskal-Wallis $(\mathrm{p}<0,05)$. Os seis extratos bloquearam o desembainhamento larvar. Após adição de PVPP, um inibidor de taninos, o percentual de desembainhamento foi similar ao PBS ( $\mathrm{p}>0,05$ ), exceto nos extratos das folhas de L. leucocephala e M. tenuiflora. Entretanto, a pré-incubação desses dois extratos com PVPP alterou significativamente o desembainhamento quando comparado com extratos náotratados ( $\mathrm{p}<0,05)$. Esses resultados sugerem que A. colubrina, L. leucocephala e M. tenuiflora podem ser úteis no controle de nematóides gastrintestinais e que os taninos são provavelmente os principais compostos envolvidos nos efeitos. Contudo, estudos toxicológicos e in vivo são necessários.

Palavras-chave: In vitro, taninos, polivinilpolipirrolidona, controle de helmintos, fitoterápicos.

\footnotetext{
${ }^{*}$ Corresponding author: Claudia Maria Leal Bevilaqua

Programa de Pós-Graduação em Ciências Veterinárias,

Universidade Estadual do Ceará - UECE, Av. Dedé Brasil 1700,

Campus do Itaperi, CEP 60740-093, Fortaleza - CE, Brazil;

e-mail: claudiamlb@yahoo.com.br
} 


\section{Introduction}

Gastrointestinal nematode parasitism remains one of the main threats to the farming of small ruminants in tropical countries. Haemonchus contortus is one of the most significant species because of its high prevalence and pathogenicity (HOUNZANGBEADOTE et al., 2005). Control of these parasites has been based on the administration of synthetic anthelmintics. However, the development of populations resistant to all of the drug families currently available (TORRES-ACOSTA; HOSTE, 2008) and concerns regarding drug residue in food and in the environment have stimulated the search for alternative control strategies (ATHANASIADOU et al., 2008).

An alternative for control of gastrointestinal nematode parasites that is being researched is the use of tanniferous plants. Promising results to keep eggs from hatching, as well as the development, motility and exsheathment of larvae, have been obtained after incubation of tannin-rich plant extracts with nematodes (BARRAU et al., 2005; BRUNET et al., 2007; MOLAN; FARAJ, 2010). Reduction of nematode egg excretion and worm burden have been also recorded in goats and sheep fed with tanniferous plants (MARLEY et al., 2003; LANGE et al., 2006; HECKENDORN et al., 2007; MINHO et al., 2008, 2010). Most studies have focused on forage legumes belonging to the Fabacea family, such as Hedysarum coronarium, Onobrychis viciifolia, Lotus corniculatus, Lotus pedunculatus and Lespedeza cuneata (HOSTE et al., 2006). Nevertheless, in many small ruminant production systems, cultivated forage plants are not the main feed source because browser plants (bushes, trees or shrubs) contribute significantly to the nutrition of these animals during a prolonged dry period (MANOLARAKI et al., 2010), which occurs in tropical countries (SANON et al., 2008).

The aim of this study was to evaluate the effect of leaf and stem extracts of Anadenanthera colubrina, Leucaena leucocephala and Mimosa tenuiflora on the exsheathment of infective $H$. contortus larvae in vitro. The role of tannins in this process was analyzed after polyvinyl polypyrrolidone (PVPP), a tannin inhibitor, was added. These plants were chosen because of their prevalence in semi-arid regions of Brazil and other tropical countries; these species are also used in small ruminants' feed and are tannin-rich (KANANI et al., 2006; MONTEIRO et al., 2006; RIVERA-ARCE et al., 2007).

\section{Material and Methods}

\section{Plant and extract preparation}

Aerial parts of $A$. colubrina, L. leucocephala and M. tenuiflora were collected in December 2009 in Fortaleza, State of Ceará, located in northeastern Brazil. Prior to the beginning of the trial, samples of the plants were identified and authenticated by botanists at the Herbarium Prisco Bezerra of the Universidade Federal do Ceará, Brazil. A voucher specimen of each species was deposited under the numbers 46022, 45875 and 46018, respectively.

A. colubrina, L. leucocephala and $M$. tenuiflora extracts were prepared as described by Barrau et al. (2005). Leaves (150 g) and stems $(150 \mathrm{~g})$ of each plant were separately air-dried at room temperature, crushed to a powder and then mixed with $2 \times 900 \mathrm{~mL}$ of acetone/water (70:30). The acetone was removed under low pressure using a rotary evaporator, and the aqueous solution was washed 4 times with $500 \mathrm{~mL}$ methylene chloride to remove chlorophyll and lipids. The remaining fractions, called leaf extract and stem extract of $A$. colubrina, L. leucocephala and $M$. tenuiflora, were freeze-dried and kept refrigerated at $4{ }^{\circ} \mathrm{C}$ in airtight containers until use.

\section{Chemical analysis of extracts}

The phytochemical test to detect the presence of hydrolyzable or condensed tannins was performed, following the method described by Matos (2009). The extracts were diluted in alcohol, three drops of ferric chloride $\left(\mathrm{FeCl}_{3}\right)$ solution were added and the mixture was shaken. The formation of a dark blue precipitate indicated the presence of hydrolyzable tannins, and a green precipitate indicated the presence of condensed tannins. Samples were compared to a control, e.g., a mixture of water and ferric chloride solution.

The content of total phenol was determined using the FolinCiocalteu spectrophotometric method (BONOLI et al., 2004). Briefly, $100 \mu \mathrm{L}$ of each extract solution (150 ppm) was shaken for 1 minute with $500 \mu \mathrm{L}$ of Folin-Ciocalteu reagent and $6 \mathrm{~mL}$ of distilled water. Then, $2 \mathrm{~mL}$ of $15 \%$ sodium carbonate $\left(\mathrm{Na}_{2} \mathrm{CO}_{3}\right)$ was added and the mixture was shaken again for 30 seconds. The solution was adjusted to $10 \mathrm{~mL}$ by adding distilled water. After 2 hours, the absorbance at $750 \mathrm{~nm}$ was evaluated using a spectrophotometer. The readings, with three replicates per sample, were performed with a negative control. The total phenol content was assessed by plotting the gallic acid calibration curve. For the total tannin content, $100 \mathrm{mg} \cdot \mathrm{mL}^{-1}$ PVPP was used to isolate these metabolites from extract. Then total tannins were measured as the difference of total phenol before and after treatment with PVPP.

\section{Larval artificial exsheathment assay}

To recover $H$. contortus third-stage larvae (L3), feces were collected directly from the rectum of an experimentally infected sheep and were processed according to Roberts and O'Sullivan (1950). The isolated of $H$. contortus is benzimidazole-resistant and has been maintained in experimentally infected animals for about five years. The larvae were stored at $4{ }^{\circ} \mathrm{C}$. Twenty-four hours before the experiment, 2- to 3-months-old larvae were brought to $25^{\circ} \mathrm{C}$. The viability and proportion of exsheathed larvae were verified under microscope.

The test was performed according to Bahuaud et al. (2006). The extracts were diluted in phosphate buffer solution (PBS), and the concentration evaluated was $300 \mu \mathrm{g} \cdot \mathrm{mL}^{-1}$. Then, approximately 1,000 ensheathed L3 were incubated for 3 hours at $20^{\circ} \mathrm{C}$ with each extract. The larvae were washed and centrifuged three times in PBS ( $\mathrm{pH}$ 7.2). Thereafter, the L3 were subjected to the process of artificial exsheathment by incubation in a solution of sodium hypochlorite $(2 \% \mathrm{w} / \mathrm{v})$ diluted 1:300 in PBS and divided in 7 aliquots. The kinetics of larval exsheathment were monitored under a microscope, and exsheathed larvae were counted at 0,10 , $20,30,40,50$ and 60 minutes after contact with the hypochlorite 
solution. The identification and count of ensheathed and exsheathed larvae were realized after the addition of drops of lugol. PBS was used as a negative control. Six replicates were performed for each extract and for the control.

\section{Effects of PVPP addition to plant extracts on larval exsheathment}

To evaluate the role of tannins in the assay, PVPP, a specific inhibitor of tannins, was added to leaf and stem extracts of A. colubrina, L. leucocephala and $M$. tenuiflora. PVPP is capable of forming bonds with tannins and can precipitate them from solutions. Comparisons of the results obtained with extracts with or without PVPP confirmed the involvement of these metabolites. Each extract was pre-incubated overnight with $50 \mathrm{mg} \cdot \mathrm{mL}^{-1}$ PVPP (ALONSO-DÍAZ et al., 2008a; 2008b) and then tested as previously described. A negative control with PBS was included in the test.

\section{Statistical analysis}

The percentage of larval exsheathment in each treatment was determined by the Equation 1:

$$
\left(\frac{\text { Number of exsheathed L3 }}{\begin{array}{c}
\text { Number of } \\
\text { ensheathed L3 }
\end{array}} \begin{array}{c}
\text { Number of } \\
\text { exsheathed L3 }
\end{array}\right) \times 100
$$

Data were initially subjected to the Shapiro-Wilk and Bartellet tests to confirm the normality of distribution and the homogeneity of variance between treatments, respectively. Even after data transformation, there was no homoscedasticity; then, the KruskalWallis test $(\mathrm{p}<0.05)$ was applied using SAS (2002). Data were expressed as mean \pm standard error (S.E.).

\section{Results}

\section{Chemical analysis of extracts}

The yields of $A$. colubrina, L. leucocephala and $M$. tenuiflora leaf extracts, after lyophilization, were 9,8 and $11 \%$, respectively, whereas the stem extract yields were 11, 13 and 17\%, respectively. In all extracts, the presence of condensed tannins was detected. Table 1 shows the total phenols and tannins of the extracts.

\section{Larval artificial exsheathment assay}

Figures 1, 2 and 3 demonstrate the results of the larval artificial exsheathment assay. In the negative control, $>99 \%$ of $H$. contortus L3 were exsheathed 60 minutes after contact with the sodium hypochlorite solution. Moreover, 3 hours of contact with the leaf and stem extracts of $A$. colubrina, L. leucocephala and $M$. tenuiflora completely inhibited the process, as almost all of the larvae were ensheathed and the percentage obtained was different from the PBS $(\mathrm{p}<0.05)$.
Table 1. Total phenol and tannin contents of leaf and stem extracts of Anadenanthera colubrina, Leucaena leucocephala and Mimosa tenuiflora.

\begin{tabular}{lcc}
\hline \multicolumn{1}{c}{ Plant } & Total phenols & Total tannins \\
\hline Anadenanthera colubrina & & \\
Leaf extract & 48.23 & 40.68 \\
Stem extract & 99.58 & 78.44 \\
Leucaena leucocephala & & \\
Leaf extract & 58.81 & 45.21 \\
Stem extract & 37.66 & 24.07 \\
Mimosa tenuiflora & & \\
Leaf extract & 78.73 & 30.13 \\
Stem extract & 147.91 & 138.85 \\
\hline
\end{tabular}

Results expressed as mg gallic acid per $\mathrm{g}$ of extract.
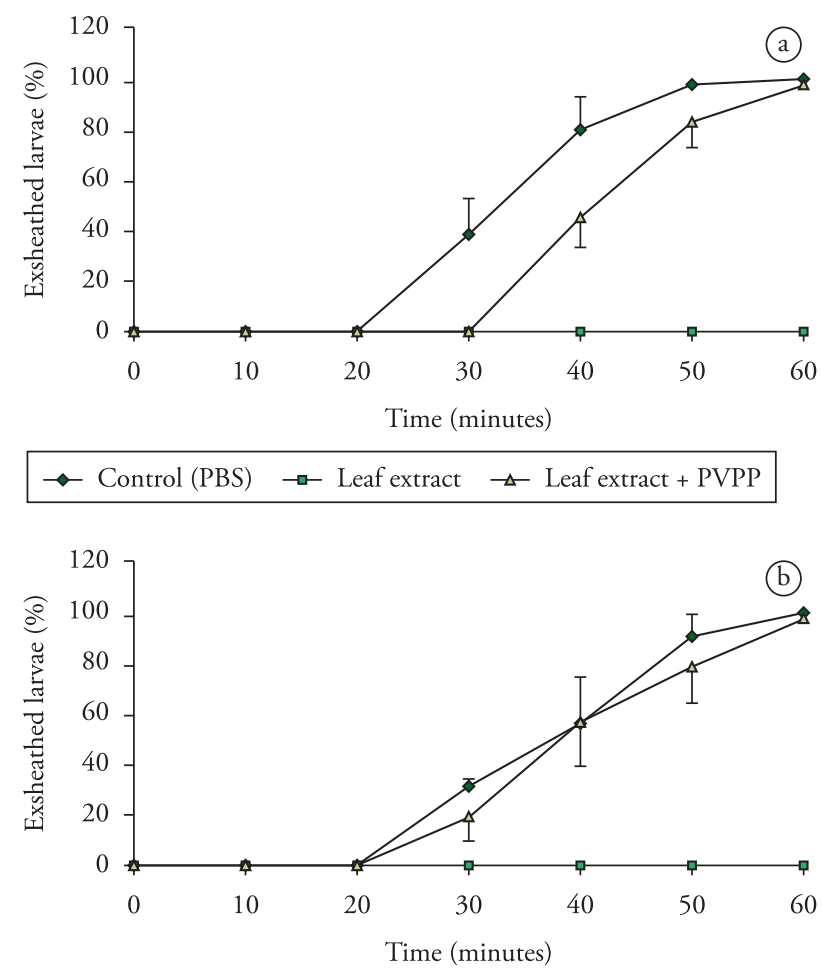

$\neg$ Control (PBS) $\rightarrow-$ Stem extract $\rightarrow-$ Stem extract + PVPP

Figure 1. Effect of leaf extract (a) and stem extract (b) of Anadenanthera colubrina, with or without addition of PVPP, on the artificial in vitro exsheathment of Haemonchus contortus third-stage larvae.

\section{Effects of PVPP addition to plant extracts on the larval exsheathment}

Pre-incubation of $A$. colubrina leaf and stem extracts with PVPP completely reversed the inhibitory effect on larval exsheathment; 60 minutes after the addition of sodium hypochlorite solution, the percentage obtained was similar to negative control $(\mathrm{p}>0.05)$ (Figures $1 \mathrm{a}$ and $\mathrm{b}$ ).

After the addition of PVPP to L. leucocephala and M. tenuiflora leaf extracts, the percentage of $H$. contortus larval exsheathment 

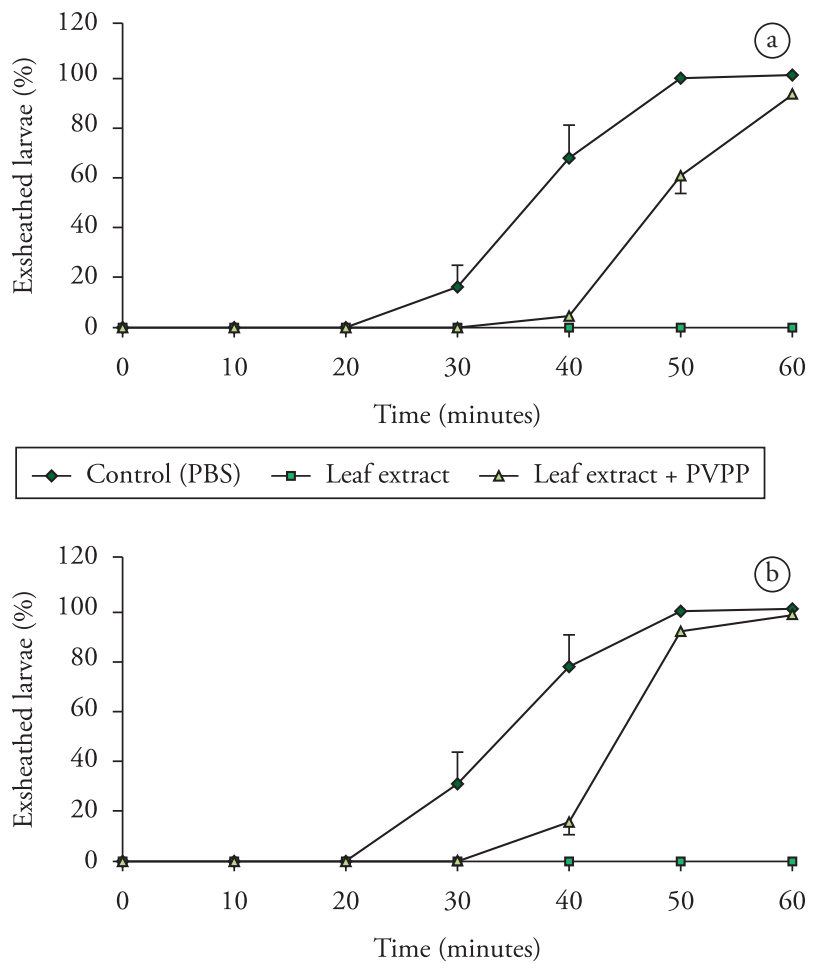

$\rightarrow$ Control (PBS) $\rightarrow-$ Stem extract $\rightarrow-$ Stem extract + PVPP

Figure 2. Effect of leaf extract (a) and stem extract (b) of Leucaena leucocephala, with or without addition of PVPP, on the artificial in vitro exsheathment of Haemonchus contortus third-stage larvae.

obtained 60 minutes after the addition of sodium hypochlorite solution was 92.27 and $84.50 \%$, respectively. This change was significant when compared with extracts not treated with PVPP $(p<0.05)$. However, the results remained significantly different from the negative control values $(\mathrm{p}<0.05)$ (Figures $2 \mathrm{a}$ and $3 \mathrm{a}$ ). Pre-incubation of $L$. leucocephala and $M$. tenuiflora stem extracts with PVPP completely reversed the inhibitory effect, as there were no significant differences when compared to the results obtained with PBS ( $p>0.05$ ) (Figures $2 b$ and $3 b$ ).

\section{Discussion}

The main objective of this study was to demonstrate in vitro that $A$. colubrina, L. leucocephala and $M$. tenuiflora extracts inhibited $H$. contortus larval exsheathment. Leguminosae is the third largest family of angiosperms, comprising 650 genera and about 18,000 species, including three subfamilies: Caesalpinioideae, Mimosoideae and Papilionoideae (BOUCHENAKKHELLADI et al., 2010). Most studies have been conducted with species of the Papilionoideae subfamily, whereas the Mimosoideae subfamily has not been well studied. This study was the first to evaluate the antiparasitic effects of $A$. colubrina and $M$. tenuiflora. With respect to L. leucocephala, the results obtained confirm those demonstrated by Alonso-Díaz et al. (2008b). These authors demonstrated $90 \%$ efficacy on $H$. contortus larval exsheathment using $1,200 \mu \mathrm{g} \cdot \mathrm{mL}^{-1}$ of $L$. leucocephala leaf extract, while this
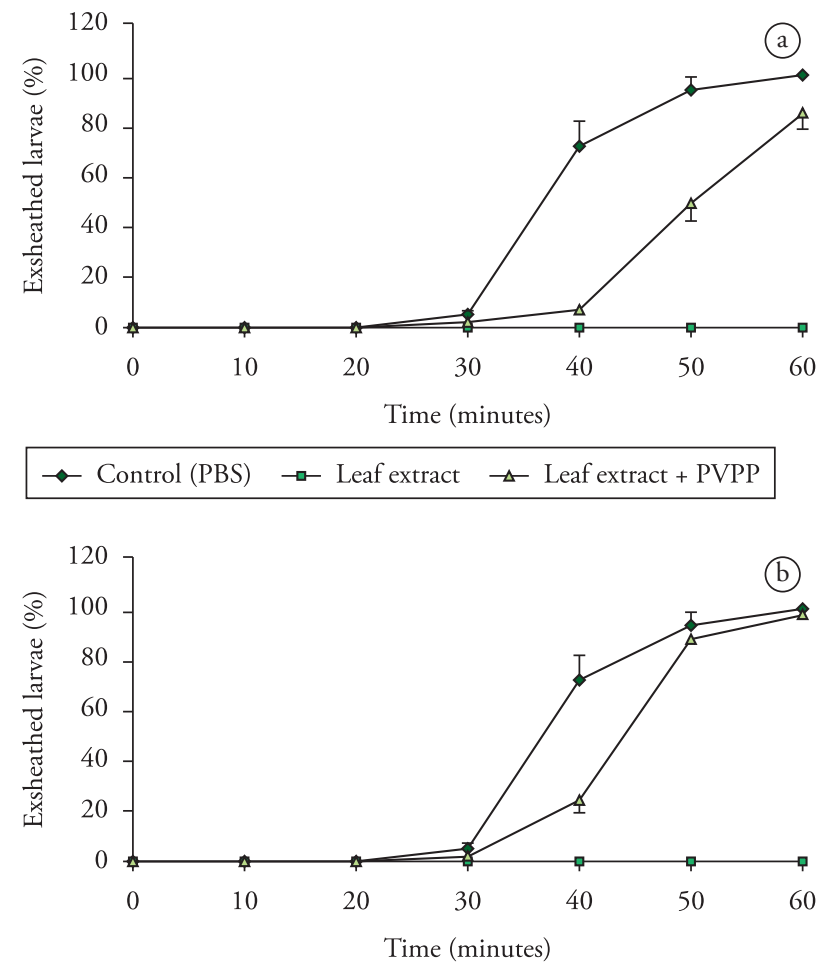

$\neg$ Control (PBS) $\rightarrow-$ Stem extract $\rightarrow$ Stem extract + PVPP

Figure 3. Effect of leaf extract (a) and stem extract (b) of Mimosa tenuiflora, with or without addition of PVPP, on the artificial in vitro exsheathment of Haemonchus contortus third-stage larvae.

study obtained $100 \%$ efficiency on larval exsheathment using $300 \mu \mathrm{g} \cdot \mathrm{mL}^{-1}$. This difference could be attributed to the plant chemical composition. Genetic factors, climate, soil, harvest time and solar radiation can influence the composition and concentration of secondary metabolites (GOBBO-NETO; LOPES, 2007).

The second objective of this study was to determine if tannins have an important role in the antiparasitic activity of $A$. colubrina, L. leucocephala and $M$. tenuiflora on $H$. contortus larvae. Condensed tannins are likely the main substances involved in the antiparasitic activity of these plants because the addition of ferric chloride solution during phytochemical analysis produced a green precipitate, indicating the predominance of these metabolites. Two hypotheses, based on the direct and indirect effects of tannins, have been proposed to explain their antiparasitic effect. However, the exact mechanisms of action of these metabolites remain obscure and could differ depending on the parasite, its stage of development and possibly, the biochemical characteristics of the forage species (HOSTE et al., 2006).

The fact that tanniferous plant extracts demonstrated activity against nematodes in vitro supports the hypothesis of a direct effect for tannins. The assay conducted in this study has been routinely used in other experiments. Bahuaud et al. (2006), Brunet et al. (2007), Alonso-Díaz et al. (2008a, 2008b) found retardation or inhibition of $H$. contortus and Trichostrongylus colubriformis larval exsheathment after incubation with tanniferous plant extracts. The assumption is that condensed tannins complex with the 
sheath proteins of nematodes, which have high proline content and prevent exsheathment (BRUNET et al., 2007).

A relationship between the total phenol and tannin contents and effectiveness of $A$. colubrina, L. leucocephala and $M$. tenuiflora extracts on $H$. contortus larval exsheathment could not be established because the results were similar for different concentrations of these metabolites. This observation supports the hypothesis that the chemical structure of condensed tannins is one of the factors modulating their antiparasitic efficacy (HOSTE et al., 2006). In vitro experiments showed that prodelphinidin monomers and flavan-3-ol gallates were more active on the egg hatching, larvae motility and exsheathment of $H$. contortus, Teladorsagia circumcincta, T. colubriformis than procyanidins monomers and flavan-3-ol (MOLAN et al., 2003; BRUNET; HOSTE, 2006).

The supposition that the tannins in A. colubrina, L. leucocephala and $M$. tenuiflora extracts are primarily responsible for $H$. contortus larval exsheathment inhibition was confirmed by pre-incubation of extracts with PVPP, a synthetic polymer that has the ability to bind tannins and to inactivate their biological properties. Although the addition of this polymer to some plant extracts did not result in obtaining values similar to PBS, the substantial restoration observed indicates an involvement of tannins in this process. However, the action of other secondary metabolites should not be discarded. Barrau et al. (2005) showed that flavonoid glycosides could also interfere with the biology of $H$. contortus and emphasized the similarity between the chemical structures of tannins and flavonoids glycosides, suggesting a similar or close mechanism of action for both types of compounds.

The results of this study indicate that $A$. colubrina, L. leucocephala and $M$. tenuiflora extracts can be used to control gastrointestinal nematodes of small ruminants. However, in vivo studies should be conducted to evaluate the toxicity and anthelmintic activity of these plants.

\section{Acknowledgements}

The authors would like to thank Banco do Nordeste (BNB) for financial support and Coordenação de Aperfeiçoamento de Pessoal de Nivel Superior (CAPES) for a scholarship. Dr. Bevilaqua has a grant from the Conselho Nacional de Desenvolvimento Cientifico e Tecnológico (CNPq).

\section{References}

ALONSO-DÍAZ, M. A. et al. Effects of four tropical tanniniferous plant extracts on the inhibition of larval migration and the exsheathment process of Trichostrongylus colubriformis infective stage. Veterinary Parasitology, v. 153, n. 1-2, p. 187-192, 2008a. http://dx.doi. org/10.1016/j.vetpar.2008.01.011

ALONSO-DÍAZ, M. A. et al. In vitro larval migration and kinetics of exsheathment of Haemonchus contortus larvae exposed to four tropical tanniniferous plant extracts. Veterinary Parasitology, v. 153, n. 3-4, p. 313-319, 2008b. http://dx.doi.org/10.1016/j.vetpar.2008.01.042

ATHANASIADOU, S.; HOUDIJK, J.; KYRIAZAKIS, I. Exploiting synergisms and interactions in the nutritional approaches to parasite control in sheep production systems. Small Ruminant
Research, v. 76, n. 1-2, p. 2-11, 2008. http://dx.doi.org/10.1016/j. smallrumres.2007.12.016

BAHUAUD, D. et al. Effects of four tanniferous plant extracts on the in vitro exsheathment of third-stage larvae of parasitic nematodes. Parasitology, v. 132, n. 4, p. 545-554, 2006. PMid:16388690. http://dx.doi.org/10.1017/S0031182005009509

BARRAU, E. et al. Effect of bioactive compounds from Sainfoin (Onobrychis viciifolia Scop.) on the in vitro larval migration of Haemonchus contortus: role of tannins and flavonol glycosides. Parasitology, v. 131, n. 4, p. 531-538, 2005. PMid:16174418. http://dx.doi.org/10.1017/ S0031182005008024

BONOLI, M. et al. Antioxidant Phenols in Barley (Hordeum vulgare L.) Fluor: Comparative Spectrophotometric Study among Extraction Methods of Free and Bound Phenolic Compounds. Journal of Agricultural and Food Chemistry, v. 52, n. 16, p. 5195-5200, 2004. PMid:15291496. http://dx.doi.org/10.1021/jf040075c

BOUCHENAK-KHELLADI, Y. et al. The evolutionary history and biogeography of Mimosoideae (Leguminosae): An emphasis on African acacias. Molecular Phylogenetics and Evolution, v. 57, n. 2, p. 495-508, 2010. PMid:20696261. http://dx.doi.org/10.1016/j.ympev.2010.07.019

BRUNET, S. et al. The kinetics of exsheathment of infective nematode larvae is disturbed in presence of tannin-rich plant (sainfoin) both in vitro and in vivo. Parasitology, v. 134, n. 9, p. 1253-1262, 2007. PMid:17346358. http://dx.doi.org/10.1017/S0031182007002533

BRUNET, S.; HOSTE, H. Monomers of Condensed Tannins Affect the Larval Exsheathment of Parasitic Nematodes of Ruminants. Journal of Agricultural and Food Chemistry, v. 54, n. 20, p. 7481-7487, 2006. PMid:17002411. http://dx.doi.org/10.1021/jf0610007

GOBBO-NETO, L.; LOPES, N. P. Plantas medicinais: fatores de influência no conteúdo de metabólitos secundários. Química Nova, v. 30, n. 2, p. 374-381, 2007. http://dx.doi.org/10.1590/S010040422007000200026

HECKENDORN, F. et al. Individual administration of three tanniferous forage plants to lambs artificially infected with Haemonchus contortus and Cooperia curticei. Veterinary Parasitology, v. 146, n. 1-2, p. 123-134, 2007. PMid:17336459. http://dx.doi.org/10.1016/j.vetpar.2007.01.009

HOSTE, H. et al. The effects of tannin-rich plants on parasitic nematodes in ruminants. Trends in Parasitology, v. 22, n. 6, p. 256-261, 2006. http://dx.doi.org/10.1016/j.pt.2006.04.004

HOUNZANGBE-ADOTE, M. S. et al. In vitro effects of four tropical plants on three life-cycle stages of the parasitc nematode, Haemonchus contortus. Research in Veterinary Science, v. 78, n. 2, p. 155-160, 2005. PMid:15563923. http://dx.doi.org/10.1016/j.rvsc.2004.05.009

KANANI, J.; LUKEFAHR, S. D.; STANKO, R. L. Evaluation of tropical forage legumes (Medicago sativa, Dolichos lablab, Leucaena leucocephala and Desmanthus bicornutus) for growing goats. Small Ruminant Research, v. 65, n. 1-2, p. 1-7, 2006. http://dx.doi.org/10.1016/j. smallrumres.2005.04.028

LANGE, K. C. et al. Effect of sericea lespedeza (Lespedeza cuneata) fed as hay, on natural and experimental Haemonchus contortus infections in lambs. Veterinary Parasitology, v. 141, n. 3-4, p. 273-278, 2006. PMid:16857320. http://dx.doi.org/10.1016/j.vetpar.2006.06.001

MANOLARAKI, F. et al. Anthelmintic activity of some Mediterranean browse plants against parasitic nematodes. Parasitology, v. 137, n. 4, p. 685-696, 2010. PMid:19961649. http://dx.doi.org/10.1017/ S0031182009991399 
MARLEY, C. L. et al. The effect of birdsfoot trefoil (Lotus corniculatus) and chicory (Cichorium intybus) on parasite intensities and performance of lambs naturally infected with helminth parasites. Veterinary Parasitology, v. 112, n. 1-2, p. 147-155, 2003. http://dx.doi. org/10.1016/S0304-4017(02)00412-0

MATOS, F. J. A. Introduçáo à fitoquímica Experimental. 3. ed. Fortaleza: UFC, 2009. 45 p.

MINHO, A. P. et al. Effect of Acacia molissima tannin extract on the control of gastrointestinal parasites in sheep. Animal Feed Science and Technology, v. 147, n. 1-3, p. 172-181, 2008. http://dx.doi. org/10.1016/j.anifeedsci.2007.09.016

MINHO, A. P. et al. Efficacy of condensed tannin presents in acacia extract on the control of Trichostrongylus colubriformis in sheep. Ciência Rural, v. 40, n. 6, p. 1360-1365, 2010. http://dx.doi.org/10.1590/ S0103-84782010005000088

MOLAN, A. L. et al. Effect of flavan-3-ols on in vitro egg hatching, larval development and viability of infective larvae of Trichostrongylus colubriformis. International Journal for Parasitology, v. 33, n. 14, p. 1691-1698, 2003. http://dx.doi.org/10.1016/S0020-7519(03)00207-8

MOLAN, A. L.; FARAJ, A. M. The effects of condensed tannins extracted from different plant species on egg hatching and larval development of Teladorsagia circumcincta (Nematoda: Trichostrongylidae). Folia Parasitologica, v. 57, n. 1, p. 62-68, 2010.
MONTEIRO, J. M. et al. Use and traditional management of Anadenanthera colubrina (Vell.) Brenan in the semi-arid region of northeastern Brazil. Journal of Ethnobiology and Ethnomedicine, v. 2, n. 6, p. 1-7, 2006. http://dx.doi.org/10.1186/1746-4269-2-6

RIVERA-ARCE, E. et al. Pharmacognostical studies of the plant drug Mimosae tenuiflorae cortex. Journal of Ethnopharmacology, v. 113, n. 3, p. 400-408, 2007. PMid:17709219. http://dx.doi.org/10.1016/j. jep.2007.06.023

ROBERTS, F. H. S.; O'SULLIVAN, P. J. Methods for egg counts and larval cultures for strongyles infecting the gastrointestinal tract of cattle. Australian Journal of Agricutural Research, v. 1, n. 1, p. 99-102, 1950. http://dx.doi.org/10.1071/AR9500099

SANON, H. O.; KABORÉ-ZOUNGRANA, C.; LEDIN, I. Nutritive value and voluntary feed intake by goats of three browse fodder species in the Sahelian zone of West Africa. Animal Feed Science and Technology, v. 144, n. 1-2, p. 97-110, 2008. http://dx.doi.org/10.1016/j. anifeedsci.2007.10.004

SAS INSTITUTE. SAS/STAT. User's guide. Cary, NC, 2002.

TORRES-ACOSTA, J. F. J.; HOSTE, H. Alternative or improved methods to limit gastro-intestinal parasitism in grazing sheep and goats. Small Ruminant Research, v. 77, n. 2-3, p. 159-173, 2008. http://dx.doi.org/10.1016/j.smallrumres.2008.03.009 